\title{
An Analytical Method for Generating a Data Set for a Neural Model of a Conveyor Line
}

\author{
Pihnastyi Oleh \\ Department of distributed \\ information systems and cloud \\ technologies, \\ National Technical University \\ "KPI" \\ Kharkiv, Ukraine \\ pihnastyi@gmail.com
}

\author{
Kozhevnikov Georgii \\ Department of distributed \\ information systems and cloud \\ technologies, \\ National Technical University \\ "KPI" \\ Kharkiv, Ukraine \\ kozhevnikov.gk@gmail.com
}

\author{
Bondarenko Tetiana \\ Department of computer \\ information technologies and \\ mathematics \\ Ukrainian Engineering-Pedagogics \\ Academy \\ Kharkiv, Ukraine \\ bondarenko_tc@uipa.edu.ua
}

\begin{abstract}
Models using neural networks are a rather promising class of models for designing highly efficient control systems for a dynamic distributed transport system of the conveyor type. An important problem in constructing a model of a conveyor-type transport multi-section system is the formation of a data set for training a neural network. This study discusses a method for generating data for training a neural network based on an analytical model of a conveyortype transport system. A detailed analysis of the most common models of the transport conveyor is performed and the choice of an analytical model for the formation of a training data set is theoretically justified. An algorithm for calculating the flow parameters of individual sections of the transport system is proposed. An estimation of the transition period is given. Graphical representation of a data set for training a neural network using an analytical model of a transport system is demonstrated.
\end{abstract}

Keywords-conveyor, flow control, artificial intelligence, dynamic distributed system, ANN model

\section{REFERENCES}

[1] O. Pihnastyi, "Statistical theory of control systems of the flow production", LAP LAMBERT Academic Publishing, Beau Bassin, $\mathrm{p}$. 436, 2018.

[2] Siemens, "Innovative solutions for the mining industry" 2018; www.siemens.com/mining.

[3] "ConveyorBeltGuide Engineering: Conveyor components"; http://conveyorbeltguide.com/engineering.html.

[4] W. Kung, " The Henderson Coarse Ore Conveying System-A Review of Commissioning, Start-up, and Operation", Bulk Material Handling by Belt Conveyor 5,Society for Mining, Metallurgy and Exploration, Inc., 2004.

[5] M. Alspaugh, "Latest developments in belt conveyor technology," MINExpo, New York, Las Vegas, NV, USA, 2004.

[6] M. Alspaugh, "Longer Overland Conveyors with Distributed Power," Rockwell Automation Fair, St Louis, MO USA, 2005; http://www.overlandconveyor.com/pdf/Longer_Overland_C onveyors_with_Distributed_Power.pdf

[7] O. Pihnastyi and V. Khodusov, "Model of a composite magistral conveyor line," IEEE International Conference on System analysis \& Intelligent computing (SAIC 2018), pp. 68-72, 2018.

[8] L. Nordell and Z. Ciozda, "Transient belt stresses during starting and stopping: Elastic response simulated by finite element methods," Bulk Solids Handling, vol. 4(1), pp. 99-104, 1984; http://www.ckit.co.za/secure/conveyor/papers/troughed/transient/tr ansient-belt-stresses.htm

[9] D. He, Y. Pang, G. Lodewijks and X. Liu, "Determination of Acceleration for Belt Conveyor Speed Control in Transient Operation," International Journal of Engineering and Technology, vol. $\quad 8(3), \quad$ pp. $206-211, \quad 2006$; http://dx.doi.org/10.7763/IJET.2016.V8.886
[10] B. Karolewski and P. Ligocki, "Modelling of long belt conveyors," Maintenance and reliability, vol. 16 (2), pp. 179-187, 2014; http://yadda.icm.edu.pl/yadda/element/bwmeta1.element.baztechce355084-3e77-4e6b-b4b5-ff6131e77b30

[11] R. Pascual, V. Meruane and G. Barrientos, "Analysis of transient loads. on cable-reinforced conveyor belts with damping consideration," XXVI Iberian Latin-American Congress on Computational Methods in Engineering, pp.1-15, 2005.

[12] C. Wheeler, "Predicting the main resistance of belt conveyors," BELTCON 12 - International Materials Handling Conference, 2003; http://www.saimh.co.za/beltcon/beltcon12/paper1208.htm

[13] T. Mathaba and X. Xia, "A parametric energy model for energy management of long belt conveyors," Energies, vol. 8(12), 2015; 13590-13608.

[14] A. Reutov, "Simulation of load traffic and steeped speed control of conveyor," in: IOP Conference Series: Earth and Environmental, vol. 87, pp. 1-4, 2017.

[15] E. Wolstenholm, "Designing and assessing the benefits of control policies for conveyor belt systems in underground mines," Dynamica, vol. 6(2), pp. 25-35, 1980.

[16] O. Pihnastyi, "Control of the belt speed at unbalanced loading of the conveyor," Scientific bulletin of National Mining University, vol. (6), pp. 122-129, 2019; https://doi.org/10.29202/nvngu/2019-6/18

[17] O. Pihnastyi and V. Khodusov, "Model of conveyer with the regulable speed," Bulletin of the South Ural State University. Ser. Mathematical Modelling, Programming and Computer Software, vol. 10 (4), pp. 64-77, 2017; https://doi.org/10.14529/mmp170407.

[18] O. Pihnastyi and V. Khodusov, "Calculation of the parameters of the composite conveyor line with a constant speed of movement of subjects of labour," Scientific bulletin of National Mining University. no. 4 (166), pp. 138-146, 2018;

[19] A. Kirjanów, "The possibility for adopting an artificial neural network model in the diagnostics of conveyor belt splices" Interdisciplinary issues in mining and geology, vol.6, pp.1-11, 2016

[20] D. Więcek, A. Burduk, I. Kuric, "The use of ANN in improving efficiency and ensuring the stability of the copper ore mining process," Acta Montanistica Slovaca, vol. 24, pp. 1-14, 2019

[21] Xi Pingyuan and Song Yandong, "Application Research on BP Neural Network PID Control of the Belt Conveyor," JDIM, vol. 9(6), pp. 266-270, 2011.

[22] M. Andrejiova and D. Marasova, "Using the classical linear regression model in an.alysis of the dependences of conveyor belt life," Acta Montanistica Slovaca, vol. 18(2), pp. 77-84, 2013; https://actamont.tuke.sk/pdf/2013/n2/2andrejiova.pdf

[23] O. Pihnastyi and V. Khodusov, "Optimal Control Problem for a Conveyor-Type Production Line," Cybern. Syst. Anal. Springer US, vol. 54, no. 5, pp. 744-753, 2018; DOI:https://doi.org/10.1007/s10559-018-0076-2

[24] O. Pihnastyi, "Test data set for the conveyor transport system," Mendeley Data, vol. 4, 2020. http://dx.doi.org/10.17632/4vcb843t76.4 